\title{
Tertiary Non-English Majors' Attitudes towards Autonomous Technology-Based Language Learning
}

\author{
Thao Quoc Tran ${ }^{1, *}$ Huy Duong ${ }^{2}$
}

\author{
${ }^{1}$ Ho Chi Minh City University of Technology (HUTECH), Vietnam \\ ${ }^{2}$ Da Lat University, Vietnam \\ ${ }^{*}$ Corresponding author: Thao Quoc Tran. Email: tq.thao@hutech.edu.vn
}

\section{ABSTRACT}

Technology has emerged as an indispensable part of general education and, in particular, English language education. Accordingly, the utilization of technology for autonomous language learning (ALL) should be imperative. Therefore, this research aims to scrutinize non-English majors' attitudes towards autonomous technology-based language learning (ATLL) at the context of Da Lat University. The research participants were 425 non-English majors conveniently sampled answering the closed-ended questionnaires, and 25 of whom were invited for semi-structured interviews. The quantitative data from questionnaires were processed by SPSS, while the qualitative data from interviews were analyzed employing the content analysis approach. The results unraveled that the research participants had positive attitudes towards ATLL. Among three components of attitudes, it was found out that non-English majors were highly conscious of the important roles of technology in ALL (cognitive attitudes), they had positive feelings towards the use of technology in ALL (affective attitudes), and they were unsure of activities for using technology for ALL (behavioral attitudes). Such preliminary results are expected to contribute to understanding the enhancement of learner autonomy by integrating technology into autonomous English language teaching and learning.

Keywords: attitude, autonomy, non-English major, technology, language learning

\section{INTRODUCTION}

In language education, the emergence of technology has become pivotal. The typical forms of using technologies in learning languages are ComputerAssisted Language Learning (CALL) [1], e-tandem learning [2], and computer-mediated communication (CMC) [3]. F. Hayta et al. (2013) [4] states that CALL is one of four important terms to sharpen the meaning of autonomous learning, and CALL refers to the need to provide the necessary software to facilitate autonomous learning properly. The technology-based approach highlights learners' independent interactions in the process of their use of educational technologies, and Internet-based activities including emails and online discussion platforms can boost learner autonomy [5]. Additionally, A. Arifah (2014) [6] asserts that learners can learn meaningfully when they use internet-connected computers in their learning process. Technology can help them develop their thinking skills in a higher order.

In the context of Vietnam, technology has been used to teach English in several high schools and universities in recent years. The development and application of Information and Communication Technology (ICT) have considerable impacts on language learner autonomy in Vietnam [7-9]. The increasing use of ICT has clearly changed the English learning methodologies. Through using technology to learn the English language better and faster, EFL learners can manage the process of their own learning and get access to many useful online resources, study software, and online dictionaries (ibid.). In Da Lat University, there are many technology-based facilities such as an Electronic library, multimedia rooms, LAB, Iclass, smart classrooms, self-study rooms with Wi-Fi internet aiming to help students study English. As such, students are required to take responsibility to learn independently. It is observed that, nonetheless, students, especially non-English majors, still have a low level of English proficiency and learner autonomy due to a number of reasons. Firstly, non-English majors may not like using technology in their English language learning. Secondly, they may not be autonomous English learners by themselves. Thirdly, they may encounter different obstacles to English language learning. Fourthly, they may not be able to utilize technology-based tools to learn English effectively. Therefore, to seek the plausible answers to such problems, this study, within the delimitation of this paper, endeavors to scrutinize non- 
English majors' attitudes towards autonomous technology-based language learning (ATLL) in the context of Da Lat University. The following research question must be addressed:

- What are non-English majors' attitudes towards ATLL at Da Lat University?

\section{LITERATURE REVIEW}

Scholars [10-12] have pinpointed the characteristics of autonomous learners. L. Dickinson (1993) [11] suggests that autonomous learners are characteristically able to identify the taught knowledge, determine their own learning goals, choose and employ appropriate learning strategies, identify unsuitable strategies, and monitor their own learning. Learners' own learning show enthusiasm to set their own objectives; choosing resource materials, deciding their own techniques, time, location, and methods of monitoring and evaluating their own studies. Likewise, P. Benson (2007) [10] mentions learners who are considered autonomous have characteristics of being highly extrinsically and intrinsically motivated, having a sense of agency and a need for achievement, and possessing self-efficacy and positive attitudes. Moreover, G. Murray (2014) [12] indicates clearly that autonomous learners have to follow certain characteristics to become independent learners, such as self-access, self-instruction, and self-regulation. In another aspect, L. Dam (1995) [13] states an autonomous learner is the one who is active in his learning process and knows how to learn and apply his knowledge in any learning stage.

Another significant feature of learner autonomy is an attitude, which is defined as the learner's feelings towards a specific topic [14]. Attitude is believed to shape the way students think, understand, feel and behave [8-9], [1519]. Attitude consists of three components, namely affect, behavior, and cognition [18-19]. Affect refers to how a person feels towards an attitude object. Behavior indicates how a person intends to do towards an attitude object; Cognition is about the beliefs towards an attitude object that a person holds [18-21]. D.E. Montano and D. Kasprzyk (2008) [22] argue attitude is what one believes about the outcome of applying the behavior and is measured by the evaluations of those outcomes similar vein, T.Q. Tran (2018) [7] maintains that "positive attitudes toward learner autonomy, together with creating favorable learning environment, should be considered as the most important factors that help to facilitate the process of becoming autonomous learners" (p. 347). Accordingly, learners' learning attitudes and selfconfidence can be enhanced under the application of technology [23]. M. Prensky (2001) [24] argues that language learners born in the era of technology can use mobile technologies for their studies in general and language learning in specific.

Prior studies have shown that different aspects of technology in relation to English language learning have been studied. Internationally, V. Chan (2003) [25] investigated the teachers' roles and responsibilities, students' making decision abilities, autonomous learning activities, and the role of autonomy. There were 508 undergraduate students and 41 English teachers sampled from Hong Kong Polytechnic University. It was found that teachers had positive attitudes towards learner autonomy, but students seemed not to be ready for autonomy. A. Monerah (2010) [26] studied college ESL students' attitudes towards classroom-based technology. Fifty students took part in answering the questions. The results presented that participants had positive attitudes towards the application of technology in the classroom, and they reckoned that technology was a very important tool in improving their learning and making them more successful in class. Another study is S. Izadpanah and M. Alavi's (2016) [27] study that sought high school EFL students' perspectives on applying technology in their English language learning. 638 Iranian high school EFL students were answering the questionnaires. The findings indicated that participants had a positive attitude towards using technology to study English language skills as well as to improve their vocabulary and grammar. In the context of Vietnam, T.H. Dang and N.H.T Nguyen (2014) [28] investigated 149 English majors' employment of ICT-based language learning at a university. The instrument for collecting data was a questionnaire. It was found that participants had positive attitudes towards the use of ICT-based language learning, and they had a desire to employ ICT more often in class. T. Q. Tran, T. M. Duong, and N. T. T. Huynh (2019) [8] conducted a study on tertiary English majors' attitudes toward TELL utilization tools-based language learning. 197 English majors were answering the questionnaires, and 20 of them taking part in interviews. It was shown that the majority of students had positive attitudes towards the use of TELL tools-based language learning, and the frequency of using these tools was very high. In addition, the results also indicated that students from different years of study had similar positive attitudes towards and frequency of using TELL tools in learning English in terms of the year of study, but students with different levels of academic achievements had different attitudes towards using TELL tools and used TELL tools to learn English differently. In brief, it is noticed that most studies focus on the students' attitudes towards the use of different types of technology in English language learning in various contexts; notwithstanding, the application of ATLL is not yet thoroughly studied. Therefore, this study aims to explore the non-English majors' attitudes towards the ATLL at Da Lat University. 


\section{RESEARCH METHODOLOGY}

\subsection{Research site and participants}

This study, which is a mixed-methods design, was conducted at Da Lat University, which offers over 33 undergraduate programs and 14 postgraduate programs, including 8 Master's programs and 6 Ph.D. programs. Proving English language proficiency is one of the requirements for all students. Before 2019, all nonEnglish majors had to finish two English levels before graduation. However, from 2019 onwards, all nonEnglish majors are not required to take English classes do not study English in class, but in order to meet the requirement of graduation, they must have one of the following certificates: TOEFL iBT, IELTS, TOEIC, PET or B1- Common European Framework of Reference for Languages (CEFR). That is why non-English majors are advised to self-study English so as to meet the English language requirement set by Da Lat University.

Research participants were 425 second-, third- and fourth-year non-English majors conveniently sampled from different faculties: Tourism Services and Tour Management, Economics and Business Administration, Information Technology, and International Studies. The majority of participants $(40.7 \%)$ were sophomores with ages ranging from 18-20 years old, $15.1 \%$ were junior old, and $40.2 \%$ were senior with ages ranging from 2123 years old and over 24 years old. Participants have learned English for a period of 2 - 6 years (20.7\%) and over six years $(72.5 \%)$, and a very small portion $(6.8 \%)$ of students have studied English in one year. Time for using technology-based devices to learn English per week was categorized into four main cohorts. The first cohort belonged to 0 to 3 hours was the highest cohort with the frequency of 308 , making up $72.5 \%$. The second cohort was 4 to 7 hours with a frequency of 78 , accounting for $18.4 \%$. The third cohort was of 8 to 11 hours with a frequency of 23 , accounting for $5.4 \%$, and the last cohort belonged to more than 12 hours was the lowest cohort and had only the frequency of 6 , accounting for $3.8 \%$. Only $5.4 \%$ of the sample spent 8 to 11 hours, and a very small portion of participants spent more than 12 hours $(3.0 \%)$ using technology-based devices to learn English per week. Technology-based devices used in English language learning were smartphones, iPad, desktop computers, laptops, computers, and Others. The vast majority of participants owned a smartphone, with the frequency of 405 making up 56.9\%. Along with smartphone, participants owned laptop computers with a frequency of 197 making up of $27.7 \%$, desktop computers with the frequency of 60 making up of $8.4 \%$, iPad and other devices with a frequency of 25 making up of $3.5 \%$.

\subsection{Research instruments}

This study employed two instruments, vizquestionnaire and interview for data collection. The adapted questionnaire from P. Winke and S. Goertler (2008) [29] features two main parts: (I) 4 items asking for participants' background information; (II) 15 items asking for students' attitudes towards ATLL (5-point Likert scale: strongly disagree to strongly agree). The Cronbach's Alpha was at .865, i.e., the reliability of the questionnaire was reliable. The semi-structured interview was employed for in-depth information and crosschecking the questionnaires' data. It has four main questions asking about students' attitudes towards ATLL.

\subsection{Procedures for data collection and analysis}

The questionnaire and interview were piloted, and modification was made to the questionnaire and interview questions. The main study was conducted. The questionnaires were administered to 450 students in person. The respondents spent around 15 minutes answering the questionnaire. However, 425 copies of returned questionnaire were valid. After the data from questionnaires had been roughly processed, five groups of students (25 students) were chosen randomly from four faculties for the semi-structured interviews. The language use for interviews was Vietnamese; all interviews were audio-recorded for later transcription.

Regarding data analysis, the quantitative data gained from questionnaires were processed using SPSS in terms of mean (M), standard deviation (SD), and percentage. The meaning of the interval mean scores is interpreted as 1-1.80: strongly disagree; 1.81-2.60: disagree; 2.61-3.40: neutral; 3.41- 4.20: agree; 4.21 - 5.00: strongly agree [28]. Meanwhile, the qualitative data generated from interviews were analyzed employing the content analysis approach. The codes S1, S2 to S25 were the interviewees. In order to make sure that the qualitative data analysis was valid and reliable, three researchers were invited to re-analyze three randomly chosen pieces of qualitative data. The convergent results were set at $95 \%$.

\section{RESULTS AND DISCUSSION}

\subsection{Results}

\subsubsection{Non-English majors' attitudes towards ATLL}

The results in Table 1 indicate the total mean score of non-English majors' attitudes towards ATLL was rather high $(\mathrm{M}=3.43 ; \mathrm{SD}=.90)$. That is, non-English majors had positive attitudes towards applying technology for ALL. Furthermore, non-English majors' affective, cognitive, and behavioral attitudes were relatively high. NonEnglish majors' cognitive attitudes $(\mathrm{M}=3.68 ; \mathrm{SD}=.90)$ were the highest component, followed by affective attitudes $(\mathrm{M}=3.48 ; \mathrm{SD}=.89)$. In comparison with the 
other two components, behavioral attitudes had the lowest mean score $(\mathrm{M}=3.14 ; \mathrm{SD}=1.0)$.

Table 1. Non-English majors' attitudes towards ATLL

\begin{tabular}{|c|l|c|c|}
\hline \multirow{2}{*}{ No. } & \multirow{2}{*}{ Attitudes } & \multicolumn{2}{|c|}{ N=425 } \\
\cline { 3 - 4 } & & $\mathbf{M}$ & SD \\
\hline 1 & Affective attitudes & 3.48 & .89 \\
\hline 2 & Cognitive attitudes & 3.68 & .90 \\
\hline 3 & Behavioral attitudes & 3.14 & 1.0 \\
\hline \multicolumn{2}{|c|}{ Total } & $\mathbf{3 . 4 3}$ & $\mathbf{. 9 3}$ \\
\hline
\end{tabular}

Table 2 shows that non-English majors had positive affective attitudes towards ATLL ( $\mathrm{M}=3.48 ; \mathrm{SD}=.89)$. Most of the non-English majors agreed that "technology makes [them] feel connected to what's going on with [their] autonomous English language learning" (item A2: $\mathrm{M}=3.63, \mathrm{SD}=.84)$. "[They] are interested in using technology to learn English autonomously because it motivates [them] to explore many topics [they] may not have seen before" (item A5: $\mathrm{M}=3.59$; $\mathrm{SD}=.94$ ), "like learning English with technology (e.g., iPad, laptop, cellphone) autonomously" (item 4: $\mathrm{M}=3.53 ; \mathrm{SD}=.94$ ), "get more actively involved in English courses that use ATLL" (item A1: $\mathrm{M}=3.37 ; \mathrm{SD}=.85$ ) and "technology makes [them] feel connected to other students in [their] autonomous English language learning" (item A3: $\mathrm{M}=3.27 ; \mathrm{SD}=.87$ ). In brief, non-English majors thought they were more active when using technology for autonomous English language learning, and they became more confident, helpful, enjoyable and interested.

Table 2. Non-English majors' affective attitudes towards autonomous technology-based language learning

\begin{tabular}{|c|l|c|c|}
\hline \multirow{2}{*}{ No. } & \multicolumn{1}{|c|}{ Affective Attitudes } & \multicolumn{1}{|c|}{ N=425 } \\
\cline { 3 - 4 } A1 & \multicolumn{1}{|c|}{ I get more actively involved in English courses that use ATLL. } & SD \\
\hline A2 & $\begin{array}{l}\text { Technology makes me feel connected to what's going on with my } \\
\text { autonomous English language learning. }\end{array}$ & 3.37 & .85 \\
\hline A3 & $\begin{array}{l}\text { Technology makes me feel connected to other students in my autonomous } \\
\text { English language learning. }\end{array}$ & 3.27 & .87 \\
\hline A4 & $\begin{array}{l}\text { I like learning English with technology (e.g., iPad, laptop, cellphone) } \\
\text { autonomously. }\end{array}$ & 3.53 & .94 \\
\hline A5 & $\begin{array}{l}\text { I am interested in using technology to learn English autonomously } \\
\text { because it motivates me to explore many topics I may not have seen } \\
\text { before }\end{array}$ & 3.59 & .94 \\
\hline \multicolumn{1}{|c|}{ Total } & $\mathbf{3 . 4 8}$ & $\mathbf{. 8 9}$ \\
\hline
\end{tabular}

Turning to the qualitative data generated from the interviews, it was evident that non-English majors had positive affective attitudes towards ATLL. They were active and independent in English learning and could control their own English learning activities. They also shared that technology was interesting, enjoyable, and interactive. Some comments are as follows:

\section{Active and self-responsible in English learning}

When learning English with my Laptop computer and Internet, I tend to be more active and self-responsible for my own learning. (S12)

\section{Control of own English learning activities}

I can control and monitor my own study activities in using ATLL. (S24)

Interesting, enjoyable, and interactive

Technology devices make my English learning interesting, enjoyable, and interactive. (S8)

It seemed that non-English majors liked learning English with technology, which significantly changed their attitudes towards ATLL. 


\section{Cognitive attitudes}

As regards the results in Table 3, it is found out nonEnglish majors expressed positive cognitive attitudes towards ATLL $(\mathrm{M}=3.68 ; \mathrm{SD}=.89)$. Most of the nonEnglish majors agreed that "the important purpose of autonomous learning English on the Internet is to get a high score in English test" (item C1: M=3.21; $\mathrm{SD}=1.0$ ) and "technology-devices can be a good supplement to support autonomous English learning" (item 2: $\mathrm{M}=3.84$; $\mathrm{SD}=.85)$. They were aware that the importance of doing autonomous English learning on the Internet (item C3: $\mathrm{M}=3.72 ; \mathrm{SD}=.88$ ) and "using technology-devices makes [them] more efficient in autonomous English learning" (item $\mathrm{C} 4$ : $\mathrm{M}=3.64 ; \mathrm{SD}=.88$ ). With regard to autonomous learning English tools, respondents also agreed that "the Internet is a useful autonomous learning English tool" (item C5: $\mathrm{M}=3.99 ; \mathrm{SD}=844$ ).

Table 3. Non-English majors' cognitive attitudes towards ATLL

\begin{tabular}{|c|l|c|c|}
\hline \multirow{2}{*}{ No. } & \multicolumn{1}{|c|}{ Cognitive Attitudes } & \multicolumn{2}{|c|}{ N=425 } \\
\cline { 3 - 4 } C1 & $\begin{array}{l}\text { The important purpose of autonomous learning English on the Internet is } \\
\text { to get a high score in English test. }\end{array}$ & 3.21 & 1.00 \\
\hline C2 & $\begin{array}{l}\text { Technology-devices can be a good supplement to support autonomous } \\
\text { English learning. }\end{array}$ & 3.84 & .85 \\
\hline C3 & I find it important to do autonomous English learning on the Internet. & 3.72 & .88 \\
\hline C4 & $\begin{array}{l}\text { Using technology-devices makes me more efficient in autonomous } \\
\text { English learning. }\end{array}$ & 3.64 & .88 \\
\hline C5 & The Internet is a useful autonomous learning English tool. & 3.99 & .84 \\
\hline \multicolumn{2}{|c|}{ Total } & $\mathbf{3 . 6 8}$ & $\mathbf{. 8 9}$ \\
\hline
\end{tabular}

Concerning the qualitative data, all of the interviewees showed their agreement that ATLL had important roles in English language learning. Some remarkable example are:

I myself think that learning English on the Internet can help me with the knowledge that I am not taught in class. I reckon that technology is an important part of language learning. (S9)

I am aware of the usefulness of the internet and use it in learning English, especially English grammar. In addition, I am able to correct my grammar mistakes easily through free English grammar exercises and tests online. (S10)

To conclude, it can be noted that ATLL helps nonEnglish majors become more autonomous in out-of-class learning activities.

\section{Behavioural attitudes}

The mean score of behavioral attitudes (Table 4) was lower than those of cognitive and affective attitudes, and it was neutral $(\mathrm{M}=3.14 ; \mathrm{SD}=1.00)$. This may reveal that non-English majored students were hesitant in using technology-based language learning autonomously. Many students were unsure about the technology-based learning activities such as "[setting] time to read books, documents and journals on the Internet in English autonomously" (item B1: M=3.01; $\mathrm{SD}=1.00$ ), "[setting] time to learn English on the Internet" (item B2: $\mathrm{M}=3.10$; $\mathrm{SD}=1.00$ ) and "[setting] time to watch TV shows in English to strengthen learning listening skills autonomously" (item B3: $\mathrm{M}=3.13$; $\mathrm{SD}=1.05$ ). With regard to the enrolling of extra online English courses to improve English autonomously, non-English majors were still uncertain of searching for an extra English course online to learn their English (item B5: M=3.03; $\mathrm{SD}=1.05)$. On the contrary, non-English majors were sure that "[they] choose their own way to learn English on the Internet autonomously without imitating others" (item $\mathrm{B} 4: \mathrm{M}=3.42 ; \mathrm{SD}=1.01$ ). All the $\mathrm{SD}$ in this category is quite high, so this means that responses to the questions were scattering. 
Table 4. Non-English majors' behavioural attitudes towards ATLL

\begin{tabular}{|c|l|c|c|}
\hline \multirow{2}{*}{ No. } & \multicolumn{1}{|c|}{ Behavioural Attitudes } & \multicolumn{1}{|c|}{ N=425 } \\
\cline { 2 - 4 } B1 & $\begin{array}{l}\text { I set time to read books, documents, and journals on the Internet in } \\
\text { English autonomously. }\end{array}$ & 3.01 & 1.00 \\
\hline B2 & I set time to learn English on the Internet autonomously. & 3.10 & 1.00 \\
\hline B3 & $\begin{array}{l}\text { I set time to watch TV shows in English to strengthen my learning } \\
\text { listening skills autonomously. }\end{array}$ & 3.13 & 1.05 \\
\hline B4 & $\begin{array}{l}\text { I choose my own way to learn English on the Internet autonomously } \\
\text { without imitating others. }\end{array}$ & 3.42 & 1.01 \\
\hline B5 & $\begin{array}{l}\text { I try to enroll an extra English course online to improve my English } \\
\text { autonomously. }\end{array}$ & 3.03 & 1.05 \\
\hline \multicolumn{1}{|c|}{ Total } & $\mathbf{3 . 1 4}$ & $\mathbf{1 . 0 2}$ \\
\hline
\end{tabular}

Students shared their behavioral attitudes towards ATLL online from the data collected from interviews. They said:

To me, learning English on the internet, I can use different learning materials such as ebooks, movies, video clips, and so on. I need to choose the materials suitable for my language proficiency. (S7)

When using ATLL online, I feel more comfortable, exciting and active. I think it is a better way to improve my language learning outside the classroom. (S22)

In summary, non-English majored students expressed positive behavioral attitudes towards ATLL. Some positive signs were listed as non-English majors showed the important role of technology-based devices in learning English outside class.

\subsection{Discussion}

The results revealed that, in general non-English majors had positive attitudes towards ATLL. Such a finding can be due to some reasons as follows. Firstly, non-English majors did not have to take English classes in their tertiary curriculum, but they were required to submit a certificate proving their English language proficiency before graduation. This can explain why they had to learn English autonomously. Secondly, most of non-English majors spent an amount of time weekly selfstudying English with technological devices. Thirdly, around $40 \%$ (170) of non-English majors were in the fourth year, and they were about to graduate, so they may have a habit of employing technology in English language learning. This finding is partially supported by that of different studies [8], [26] [30] which revealed that research participants had positive attitudes towards technology-based English language learning. It is agreed that positive attitudes can facilitate learners' responsibility for their own learning, and learners are likely to become autonomous [8-9], [15-19]. There was a common agreement among students regarding their attitudes towards ATLL. They gained an understanding of the benefits of ATLL, which resulted in an increase in their preference for English language learning. Therefore, from such positive attitudes towards ATLL, it may be said that non-English majors may have to employ different ATLL strategies so as to improve their English language proficiency.

Among three components of attitudes, non-English majors were found to express their positive affective attitudes towards ATLL. This may imply that students had good affection for ATLL. One of the plausible explanations for this finding could be the fact that all of the respondents possessed technological devices (e.g., Smartphone, iPad, Desktop computer, Laptop computer) for different uses, and they got used to using such devices in their learning in general and English language learning in specific.

With respect to cognitive attitudes, non-English majors were also found to have positive cognitive attitudes towards ATLL. This finding can indicate that non-English majors were aware of the importance of ATLL, and they believed that technology could support them in enhancing their English language skills. The reasons for this finding can be traced back from participants' positive affective attitudes, which may result in their positive cognitive attitudes towards ATLL.

Nonetheless, it was found that non-English majors had neutral attitudes towards ATLL, although their affective and cognitive attitudes towards ATLL were positive. It can be said that there is a gap between nonEnglish majors' affective and cognitive attitudes and their behavioral attitudes towards ATLL. In other words, what non-English majors felt and believed about ATLL was different from what they intended to do. 


\section{CONCLUSION}

This study has revealed that non-English majors had, in general, positive attitudes towards ATLL. However, when it comes to the components of attitudes, nonEnglish majors were found to be aware of the importance of ATLL and had good affection for ATLL, but they were not uncertain about their behavioral attitudes towards ATLL.

Some recommendations are drawn as follows. Firstly, this study indicated that there is a mismatch between students' affective and cognitive attitudes and their behavioral attitudes, so students should be motivated to employ technology for their autonomous English language learning. Secondly, they should be instructed how to use technological devices for autonomous English language learning effectively. Thirdly, as non-English majors in this research context have to take a certificate of English language proficiency on their own, they should be guided on how to make a time plan for ATLL appropriately.

Some limitations can be found in this study. This study focuses only on attitudes towards ATLL, so it should be better if more variables such as strategies for ATLL should be examined. Additionally, participants' involvement is limited to non-English majors, so the future study should involve both non-English majors and English majors.

\section{AUTHORS' CONTRIBUTIONS}

Two authors contribute equally to this paper.

\section{ACKNOWLEDGMENTS}

We would like to express the anonymous research participants for their willingness to have taken part in this study. Additionally, our sincere gratitude should go to other relevant parties who have given comments and supported us during our study. Without their unconditional help and support, we would have never been able to finish this study.

\section{REFERENCES}

[1] G. Aston, Enriching the learning environment: Corpora in ELT in: A. Wichmann, S. Fligelstone, T. McEnery, and G. Knowles (Eds.), Teaching and Language Corpora London: Longman, 1997, pp. 51-64.

[2] D. Little, Learner autonomy and second/foreign language learning in: The guide to good practice for learning and teaching in languages, linguistics and area studies. LTSN Subject Centre for Languages, Linguistics and Area Studies, University of Southampton, 2002.

[3] T.T. Dang, M. Robertson, Impacts of learning management system on learner autonomy in EFL learning, International Education Studies 3(3) (2010) 3-11.

[4] F. Hayta, Z. Yaprak, Learner autonomy and computer technology as a facilitator of autonomous language learning, Journal of educational and instructional studies in the world 03(2) (2013) 57-63.

[5] P. Benson, Teaching and Researching Autonomy in Language Learning, New York, NY Longman/Pearson Education, 2001.

[6] A. Arifah, Study on the use of technology in ELT classroom: Teachers' perspective. M.A., Thesis, Department of English and Humanities, BRAC University, Dhaka, Bangladesh, 2014.

[7] T. Q. Tran, The roles of technology in promoting English-majored students' learner autonomy: A critical look at HUTECH context, Proceedings of Conference on Technology and Science 2018 at Ho Chi Minh City University of Technology Ho Chi Minh City: Science and Technology Publishing House, 2018, pp. 344-348.

[8] T. Q. Tran, T. M. Duong, N. T. T. Huynh, Attitudes toward the use of TELL tools in English language learning among Vietnamese tertiary English majors, VNU Journal of Social Sciences and Humanities 5(5) (2019) 581-594. DOI: http://dx.doi.org/10.1172/vjossh.v5i5.498

[9] T. Q. Tran T. N.P. Tran, Attitudes toward the use of project-based learning: A case study of Vietnamese High school students, Journal of Language and $\begin{array}{llll}\text { Education } & 6(3) & \text { (2020) } & \text { 140-152. }\end{array}$ https://doi.org/10.17323/jle.2020.10109

[10] T. Q. Tran, D. X. Ngo, Attitudes towards Facebookbased activities for English language learning among non-English majors. Proceedings of the International conference 2020: Language for global competence: Finding authentic voices and embracing meaningful practices at HCMC Open University Ho Chi Minh City: Publishing House of Economics, 2020, pp.624-643.

[11] P. Benson, Autonomy and independence in language learning, London: Longman, 2007.

[12] L. Dickinson, Talking shop: Aspects of autonomous Learning: An interview with Leslie Dickinson, ELT Journal 47(1) (1993) 330-341.

[13] G. Murray, The social dimensions of learner autonomy and self-regulated learning. Studies in Self-Access Learning Journal 5(4) (2014) 320-341.

[14] L. Dam, Learner Autonomy 3: From Theory to Classroom Practice, Dublin: Authentik, 1995.

[15] R. Gardner, On the validity of affective variables in second language acquisition: conceptual and statistical considerations. Language Learning 30(2) (1980) 267-270. DOI: $10.1111 / \mathrm{j} / 1467-1770$. 1980.tb00318.x

[16] J. D. Brown, Using Surveys in language programs, Cambridge, UK: Cambridge University Press, 2001. 
[17] A. H. Eagly, S. Chaiken, The psychology of attitudes, Harcourt Brace Jovanovich College Publishers, 1993.

[18] T. Q. Tran, S. Seepho, EFL learners' attitudes toward intercultural communicative language teaching and their intercultural communicative competence development, Journal of English Studies 11 (2016) 1-40.

[19] T. N.P. Tran, T. Q. Tran, Attitudes towards the learning of culture in English language learning among Vietnamese high school students, Proceedings of the Third International TESOL Conference Promoting ELT: Diverse Perspectives and New Horizons at Ho Chi Minh City University of Education, Ho Chi Minh City: Ho Chi Minh City University of Education Publishing House, 2017, pp.233-246.

[20] T. Q. Tran, EFL students' attitudes towards learner autonomy in English vocabulary learning, English Language Teaching Educational Journal 3(2) (2020) 86-94.DOI: https://doi.org/10.12928/eltej.v3i2.2361

[21] M. Solomon, G. Bamossy, S. Askegaard, M. Hogg, Consumer Behaviour: A European Perspective (4th ed.), Essex: FT Prentice Hall, 2010.

[22] D. E. Montano, D. Kasprzyk, Theory of reasoned action, theory of planned behavior, and the integrated behavioral model. Theory, Research, and Practice, San Francisco, CA: Jossey-Bass, 2008.

[23] L. Lee, Autonomous learning through task-based instruction in fully online language courses, Language Learning \& Technology 20(2) (2016) 8197.
[24] M. Prensky, Digital natives, digital immigrants, 2001. Retrieved from http://www.marcprensky.com/writing/Prensky\%20$\% 20$ Digital $\% 20$

Natives, \%20Digital\%20Immigrants\%20-\%20 Part1.pdf

[25] V. Chan, Autonomous language learning: the teachers' perspectives: Teaching in higher education, Teaching in Higher Education 8(1) (2003) 33-50. Doi: $10.1080 / 1356251032000052311$

[26] A. Monerah, Attitudes towards the use of technology among college students who study English as a second language (ESL), Master of Education Thesis, Cleveland State University, 2010.

[27] S. Izadpanah, M. Alavi, Student-engaged Viewpoint on Technology in Learning English in Zanjan Public High Schools, Theory and Practice in Language Studies 6(4) (2016) 854-860.

[28] T.H. Dang, N.H.T Nguyen, An exploratory study of ICT use in English language learning among EFL university students, Teaching English with Technology 14(4) 2014 32-46.

[29] P. Winke, S. Goertler, Did we forget someone? Students' computer access and literacy for CALL, CALICO Journal 25(3) (2008) 482-509.

[30] E. Suvarnatemee, Factors affecting quality of life of Thai auditors: A case study of Thai auditors in general, Language Institute, Thammasat University, 2009. 